\title{
IMPLEMENTATION OF PROJECT MANAGEMENT PRINCIPLES IN SPANISH RESIDENTIAL DEVELOPMENTS
}

\author{
Eugenio PELLICER and Richard VICTORY \\ School of Civil Engineering, Universidad Politécnica de Valencia, \\ Camino de Vera, $s / n$, 46022 Valencia (Spain) \\ Phone: +34 963879 562; Fax: +34 963877 569; E-mail: pellicer@cst.upv.es
}

Received 9 December 2005; accepted 11 October 2006

\begin{abstract}
Urban development of land and subsequent residential development of buildings are closely related to construction industry. Within the industry, project management is widely applied in Anglo-Saxon countries. Nevertheless, the results obtained from the literature review conducted did not find how project management is taken into consideration in land and property management. Furthermore, this project management approach is seldom implemented in the Spanish construction industry, even in the private sector. The traditional rigidity and protectionism of the industry, along with the peculiarities of the Spanish Building Law, create a scenario where innovation is difficult to attain. Although, there is a promising future for small to medium sized project management firms to provide a very wide range of services to private clients. This paper shows how the implementation of project management principles can be attempted for residential developments in the Mediterranean Coast of Spain. An inductive approach is used as methodology. After explaining the real state process for the Spanish market, a basic outline for the implementation of project management is proposed. Project and client risk assessment, preliminary questionnaires, stages and steps, company organisation related to professional expertise, procurement strategies and contractual relationships are displayed. Finally, the model is tested by two characteristic case studies.
\end{abstract}

KEYWORDS: Project; Property; Management; Tourism; Construction

\section{INTRODUCTION}

\subsection{Project management background}

A project is a temporary endeavour undertaken to create a unique product or service (Project Management Institute, 1987). Project management or the management of projects, as defined by Morris (1994), "is a set of management practices and ideas hung around the way projects evolve as they go through their life cycle". The term "project management" first appeared in the mid twentieth century and it reflected a longer history of efforts in trying to rationalise discontinuous production practices that went back to Henry Gantt and Henri Fayol. The former created the bar chart at the beginning of the twentieth century (Gantt, 1903; Clark, 1925); Fayol (1916) established the five functions of management: to plan, to organise, to command, to coordinate and to control.

The mid-fifties saw the combination of technology and lessons learnt. The PERT/CPM techniques were developed in parallel, through the late fifties (Morris, 1994). CPM was developed in 1956 by Du Pont de Nemours, with the assistance of computer experts from Univac, for construction and maintenance of manufacturing plants. PERT was developed a

International Journal of Strategic Property Management ISSN 1648-715X print / ISSN 1648-9179 online (C) 2006 Vilnius Gediminas Technical University http://www.ijspm.vgtu.lt 
year later by the US Navy jointly with the management consultants Booz, Allen \& Hamilton and the Lockheed Corporation for the Polaris ballistic missile program.

In 1959, the first article on project management was published in a prestigious management journal (Gaddis, 1959). The product breakdown structure was first implemented by the Department of Defence and NASA to improve systems acquisitions in 1962 (Morris, 1994). Later on, the earned value approach was established to control the physical and financial progress of a project (Department of Defence, 1966). By the mid-sixties, the advances made in computer technology gave way to the matrix organisation concept (Mee, 1964; Knight, 1976). During these years, management was accepted as a science (Hopp, 2004; Chopra et al., 2004) and operations research as a profession (Churchman, 1970; Miser, 2001). They made the learning and implementation processes advance at alarming rates; experiences and lessons learnt from all sectors of industries were channelled into academic institutions, allowing for results to be available for all (Wren, 1994).

The methods and tools of project management evolved and changed throughout the years (Morris, 1994). Many authors contributed to this development: Cleland and King (1968), Archibald (1976), Stuckenbruck (1981), Kerzner (1989), Turner (1993), Morris (1994), Turner (2006) and Winch (2006), among others. Some milestones in the rise of project management included: the establishment of the International Project Management Association in 1965 and the Project Management Institute in 1969 (Morris, 1994), the concept of Total Quality Management (Deming, 1986), the first edition of the PMBok (Project Management Institute, 1987) and the standard ISO 100061997 on guidelines to quality in project management (International Organisation for Standardisation, 1997).

Project management applied to construction attracted the interest of numerous experts that reflected their contributions and proposals in many books and papers, from Barrie and Paulson (1978) to Fewings (2005). In the modern construction industry, an important factor of change is the attention being paid to the clients and their needs, which is forcing the industry into rethinking the whole procurement and contracting side of the construction process (Latham, 1994; Egan, 1998). Both authors had a huge impact and influence in United Kingdom. In fact it was from these reports that traditional contracting came under threat by other contracting and procurement routes. Within the private sector, many varied innovative forms of procurement routes and contractual relations have been used: management contracting, design and build, contracting management, build-own-operate-transfer and project management; all of them are widely explained and analysed in many books (e.g. Ashworth, 1998; Murdoch et al., 2000; Winch, 2002) and papers (e.g. Watkinson, 1992; Love et al., 1998; Love, 2002; Blayse \& Manley, 2004). The successful contracts completed using these types of procurement and contract routes are proof of the popularity of these methods. In the public sector, changes brought about by the introduction of the Public Private Partnership and the Private Finance Initiative in 1997 paved the way for alternative procurement routes other than traditional contracting. Project management and related procurement and contractual systems are gaining momentum as projects become more technically complex (Winch, 2002).

Urban development of land and subsequent property development of buildings are very closely related to construction industry; in fact, legalised land is needed to construct the building. In these fields, the literature review conducted, and related to project management, gets few relevant results. Ashworth (1998), for example, uses the expression "develop and construct" to define the process of purchasing land, obtaining planning approvals, designing, building and selling or renting. Chakrabarty (1998 and 2001) describes an integrated urban management model based on management science 
and systems theory. Partial approaches have been proposed for particular cases (e.g. Garba \& Al-Mubaiyedh, 1999; Lum et al., 2004); all of them are centred in land management without taking into consideration project management principles.

\subsection{Project management in the Spanish construction industry}

In Spain, the concept of project management was gradually implemented in the energy industry. However, it is practically nonexistent in the public sector (mainly construction) and slowly, but painfully, it is trying to introduce itself into the private sector (AEDIP, 2006). A survey carried out in 2000, among 39 Spanish consulting engineering firms, proved that, regarding to the use of procurement and contracting methods, the percentage of application of project management was less than $2 \%$ (Pellicer, 2001). No further studies have been done since then, even though it seems that the current situation is improving a little bit (AEDIP, 2006). In 2004, the Spanish Ministry of Federal Income recognized the need to embrace this kind of procurement system by the public sector (Ministerio de Hacienda, 2004). Nevertheless, it has not been implemented in the law yet.

The existing set-up within the industry is too rigid and inflexible; there are a lot of bureaucratic and legislative complexities too; state law, banks, professional bodies, insurance companies, main contractors and limited contractual relationships cause a closed shop atmosphere where protectionism does not allow very much for innovative management techniques (Ferry, 1991; Garrido-Hernández, 2002; Ministerio de Hacienda, 2004; SEOPAN, 2006). Furthermore, the educational system is closely linked to the professional bodies (Ferry, 1991; Martinez-Val, 1996).

Within the building sector, including the private residential sector, there is another obstacle in the way of project management implementation: the strict regulation imposed by the Spanish Building Law (Ministerio de Fomento, 1999). This law specifically identifies the agents that are wholly and solely responsible for administration and execution of projects. It does not recognise the authority of a project manager. The Spanish Building Law specifically states that only architects and quantity surveyors can carry out administration and management of building projects. Project management requires more skills than simply an understanding of the technical issues associated with the design and construction of buildings. It must ensure successful achievements of the project aims and client objectives through the management of the contributions from consultants, lawyers, estate agents and contractors. Architects and quantity surveyors are more at ease with the traditional procurement and contractual routes (Garrido-Hernández, 2002).

There is a great desire by a small sector within the construction industry to use the concept of project management more than what it is being used (AEDIP, 2006). However, there are many other agents (architects, quantity surveyors and large contractors) that prefer the current status quo as it benefits them more (Garrido-Hernández, 2002).

Nevertheless, the influence of the European Union on public procurement policies is considerable. This is especially important to the civil engineering branch of the construction industry, since there is, traditionally, a fundamental difference between procurement practices in the public and private sectors. Although it may take some time for the directives to be fully adhered, the legislative convergence in the European Union is unavoidable (Ferry, 1991; Janssen, 2000; European Union, 2005).

\subsection{Research approach and methodology}

The main purpose of the paper is to figure out how project management principles can be implemented in residential developments in the Mediterranean Coast of Spain. In order to 
comply with this goal, a basic model for the implementation of project management is proposed, where procurement and contractual relationships, company organisation, stages and preliminary questionnaires are displayed.

The paper is structured in four main sections. After introducing the project management background and its implementation in the Spanish construction industry, we present the context of the Spanish Mediterranean Coast as property market. Later on, our proposal is established: the real state process, the company organisation and the procurement and contracting strategies. Finally, our model is tested by two illustrative case studies.

The research described in this paper is part of an eight year exploration of the management of companies in the Spanish construction industry. This research comprised thoroughly cooperation with several firms covering all the construction process: real state companies, consulting engineering and architectural firms, and contractors. For this particular research, an in-depth analysis of a consulting company was developed in 2002 and 2003 for a fifteen month period. This company was not a usual one, just the opposite; it was carefully selected because of three important reasons:

- It dealt with the private residential housing market exclusively.

- The company handled all the real state process: from buying the land to construct the building. This implies that the company looks forward a project management approach to cope with the clients.

- Its position covered the southern Mediterranean Coast of Spain. Most of the foreign tourists are located in these areas and they are more open-minded to a project management approach than the Spanish citizens who are more comfortable with the traditional methods.

In order to carry on the research, an ethnographic approach was taken. The qualitative data and the empirical studies were the baseline for the later modelisation. Direct observa- tions, interviews, internal reports, technical documents, company directives and other type of information were used, as it is frequent in ethnographic research. Our focus was, not only the regular operation of the company, but also each one of its residential development projects. This approach was previously used by some researchers, based on the former work of Bartunek and Louis (1996). They proposed a way to analyse a genuine situation: at least one person had to get involved in the fieldwork of study for a time, completely committed to the task, whereas another individual coped with the formal dealings and coordinated the activities of the former. The authors of this paper played these roles for this particular case study, meeting twice per month in order to debate methodological topics, analyse results and obtain conclusions. The "insider" stayed in the chosen company for a fifteen month period, whereas the "outsider" supervised and lead him through this period of time. This same methodology was followed by Engwall (2003) in order to prove how any project is linked to its context, and Engwall and Jerbrant (2003) to analyse how resource allocation is implemented in project-based companies. Finally, our model was applied to two selected case studies in order to test its validity.

\section{THE SPANISH CONTEXT AND THE NEED FOR A PROJECT MANAGEMENT APPROACH}

The value of property on the Spanish Mediterranean Coast has increased in 2005 by $15 \%$, approximately (Rodríguez y R. de Acuña, 2006). Prices have risen from $1.700 € / \mathrm{m}^{2}$ for new apartments, to more than $5.000 € / \mathrm{m}^{2}$ in the more privileged areas such as Marbella (Ministerio de Fomento, 2001 and 2004; Rodríguez y R. de Acuña, 2006). The drastic shake up in urban planning, brought about by the introduction of new regional legislation on land use and urban planning, has opened up locked up land which has been so due to speculative property owners (Romero \& Lorente, 
1996; Modrego-Caballero, 2000; Fernández, 2005). This shaping up of the system has curbed ad hoc speculative developments of poor quality and in turn has brought in the residential tourist from the coast to further inland where construction indices oscillate between the 1.500 and $2.500 € / \mathrm{m}^{2}$ (Rodríguez y R. de Acuña, 2006).

There are two main types of developments regardless of the urban planning process: urban development and property development; a combination of the two is also possible. According to the Spanish Building Law (Ministerio de Fomento, 1999), the former requires a civil engineer or an architect to elaborate the urban project, whereas the later requires an architect and a quantity surveyor to carry on the building project; all these technicians are crucial players in designing, administering and executing the projects (GarridoHernández, 2002). However, a first approach to project management highlights a project manager as a technician who knows about planning, organising, designing, constructing and controlling the project on time and within budget (Kerzner, 1989). Nevertheless, this approach is not good enough for urban developments.

On the Mediterranean Coast there are a lot of small companies that work on a network basis (González et al., 1998). Each one has its unique function and all together got the work done. Most of the work undertaken is by traditional contracting. These networks are very extensive and span out to many sectors in different industries, e.g. banks, estate agents, lawyers, local authority officials, architects, quantity surveyors or accountants. If a network is well established and extensive, then its web has a large catching area. The newcomer within the catching area will have to touch base with at least one of the members of the network.

A company that tries to implement project management in the sector faces a hostile environment and needs to change its position in order to be able to survive. Maybe become an entire network or as close to one as it could get. This means that the project management firm has to be the first port of call for any would-be investor. The project management company has to play the role of the bank, estate agent, lawyer, urban planning consultant, architect, quantity surveyor and accountant, as well as all the traditional roles associated with project management.

Most of the Regional Land Laws in the Spanish Mediterranean Coast (e.g. Andalusia, Murcia and Valencia) grant the figure of the urbanizing agent as the urban developer that acts instead of the public administration (Romero \& Lorente, 1996; Modrego-Caballero, 2000; Fernández, 2005). Some companies are offering their services in doing the entire development process for the project. It goes from the conceptual stage to hand over, including land acquisition, urban planning, building approval, design, construction, marketing and selling. Some companies have been so successful that they have even included financing their own projects.

Currently, there are lots of possibilities. Many projects on the Mediterranean Coast are being planned around golf courses already constructed or in construction. These courses have areas of land, which will be developed, into private residences for foreign golf enthusiasts. These plots of land sit on large areas, which have been urbanised, or land, which has been authorised by the municipal planning regulations. This land is ready for development, needing the infrastructure works to be carried out on them prior to building houses. Developers, who sell off the plots but have no real knowledge of construction, own these large developments. They know their clientele will be foreigners retiring to the Mediterranean Coast because they have carried out extensive marketing that ascertains this. They have no time or experience in managing projects and after seeing the results of traditional contracting, they are now turning to project management as a more comprehensive and complete way of handling the projects. 
It has to be taken into consideration that Spain is the second European country with the largest amount of visiting tourists: fifty million. Of these, nearly one million have bought houses in Spain; $80 \%$ of them are Germans and British citizens (Kozak, 2002; Instituto Nacional de Estadística, 2003; Ministerio de Economía, 2003). It is estimated that in the next years there will be an increase of foreign residents setting up second homes in Spain (Pellicer et al., 2006). It is not only the pensioners who are looking at setting up homes abroad, but with the access to current e-commerce and associated technologies, many young families are leaving their native countries to go abroad and work at home in their new country of residence. To buy a second home in Spain is a good investment; Spain belongs to the Euro Zone, which implies a better comparison of prices, low risk and low interest rates (Pellicer et al., 2006).

Most of the prospective buyers come from the north of Europe and there is an immediate cultural difference. The north/south division becomes very prominent; the north tries to anticipate all eventualities beforehand and likes control and planning as opposed to the south that carries out some planning and lets things carry on until they hit a problem and embark on its solution. The working practices and trends vary and people from the north invariably find southern standards and methodologies somewhat different to what they are accustomed to. More often than not this usually has a negative effect and poisons the minds of these clients with apprehension and distrust. Given the nature of the Spanish Building Law, traditional single stage selective tendering and contracting would be forced upon them unless they resort to some other means of contracting. The need for change when dealing with Spanish clients is non-existent; they are fully confident in the current system and in fact many regard project management as overkill of such a simple process.

\section{REAL STATE DEVELOPMENT PROCESS}

Basically there are three stages in a typical real estate development project: a preliminary planning stage, a final planning stage and a project management stage. Initially a developer must own or search for a suitable property. Once it is located, its development possibilities must be checked out with the municipal planning commission. An analysis must be made to ascertain the value of the land. If the situation looks right, a letter of intent or an option to purchase the land may be arranged with the owner. Other activities should be started during this stage: to advise a financial backing of the project and to submit a preliminary development plan to the municipal planning commission for tentative approval.

In the final planning stage, capital and operating budgets must be worked out to determine if the project is financially feasible. By the end of this stage, approvals must be in hand and final budgets in place. If everything continues to appear feasible, the land is purchased (if not already owned). The time limit imposed by municipal regulations on the final plan approval must be strictly adhered.

With all necessary approvals in hand the construction of the infrastructure and the building can commence. A constant control on time, cost and quality are undertaken and the typical project management strategies may be implemented.

Nevertheless, gathering information is essential to be able to get an idea of the type of clients and land. This is a previous stage to the other three previously explained. A basic blueprint, established within the company, is needed for every client. From this investigation enough detail must be found out so as to be able to obtain an initial picture of whether the overall project strategy is feasible. Figure 1 displays a flowchart of the initial process for assessing risk. It is a three-step process. First the company has to assess the risk of taking the client; not only his/her character and credentials have to 


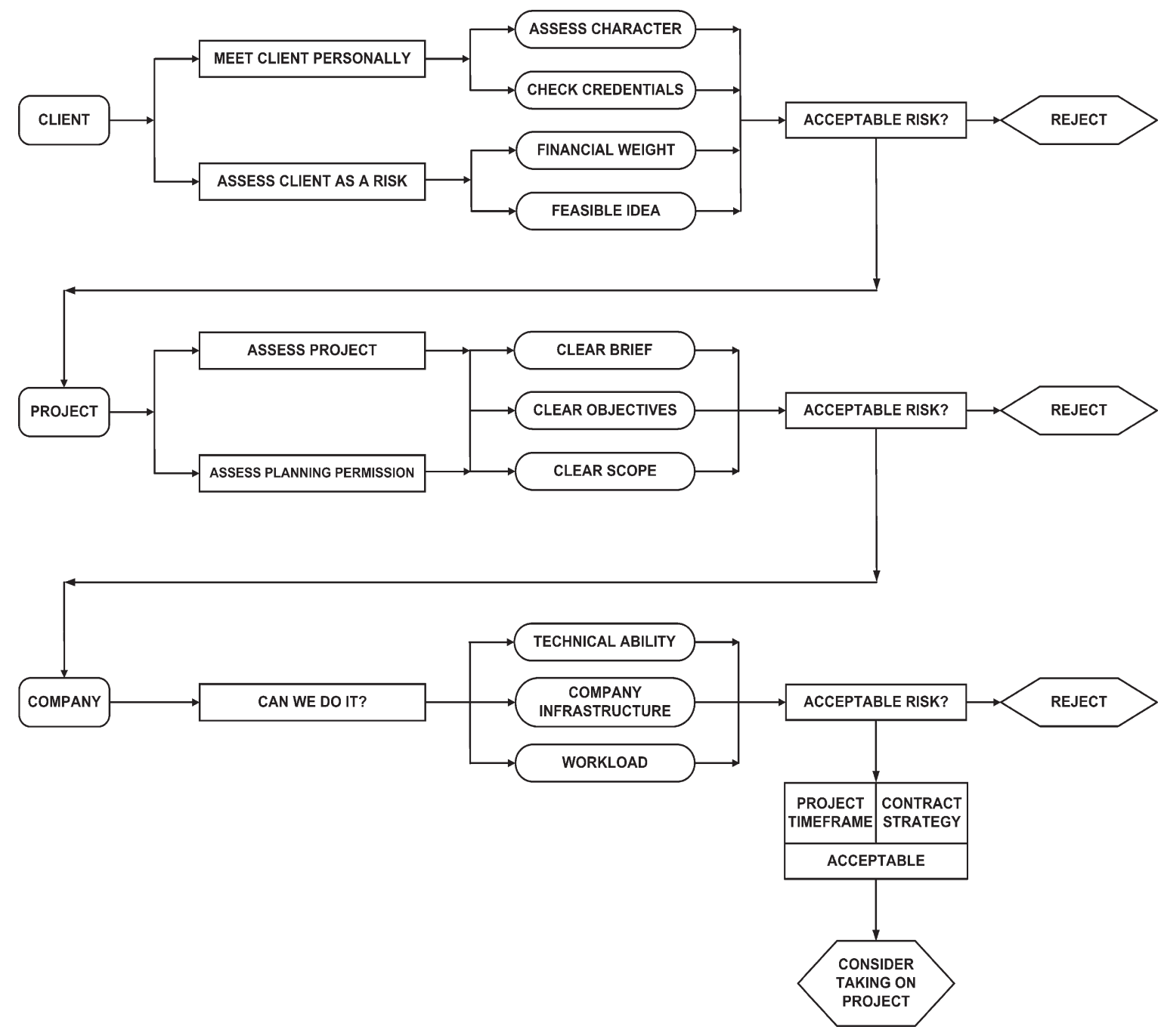

Figure 1. Flowchart of project/client risk assessment (developed by the authors)

be taken into account, but also his/her financial possibilities and the feasibility of his/her idea. The second step is focused on the assessment of project: brief, objectives and scope; the planning permission is a fundamental issue to be considered. Finally, the company has to think about if it can be done according to the technical ability of the staff, the infrastructure and, most of the time, the workload that the company has at that instance.

When a client approaches for advice for the engagement of services, some following pre- liminary questions should be clarified straight away (see Table 1). This questionnaire may be mailed, but it is essential that a face to face meeting be held, prior to any decisions to proceed be made. Once these initial questions have been asked, a decision should be taken as to whether to proceed or not. Many clients probe for information which they lack, in order to proceed with the project by themselves or with other firms; thus, some inquires of this type may lead down a blind alley.

If the decision to carry on the project is 
Table 1. Preliminary questionnaire

1. Does the client own the land?

2. Where is the land?

3. What is the size of the plot?

4. Does the client know the land classification?

5. What type of development: self-builder or urban developer?

6. Does the client have the capital or a mortgage?

7. Does the client have an architect?

8. Does the client have design drawings for the development?

9. Does the client have building permission?

10. Does the client have a schedule?

11. Does the client know how much habitable space is required?

12. What is the total budget?

13. What type of quality construction is he looking for?

14. Does the client intend to use a project manager?

15. Does the client have finance arrangements?

16. Does the client have collateral?

17. Does the client have a lawyer?

taken, then the next step is to draft an activity schedule for the client outlining the phases and the services that the company can offer. The flow chart shown in Figure 2 could be the first stage within the decision making process to ascertain the risk of the client. It is a very general chart showing the macro stage. The boxes are questions that should be asked; within each box, the project manager develops these issues, therefore there will be another micro chart for each stage. Two are the basic questions that ponder the balance towards a definition of low risk or high risk client: the ownership of land and the financial issues.

Table 2 details the steps necessary to fulfil the first phase of the flow chart showed in Figure 2 , previously to construction. The first step in the pre-construction phase means not only to study the plot but also to assess land difficulties, especially when considering environmental issues, easements, public rights to land, etc. All have a very significant role to play in the urban planning process in order to get a building license. It is very important to ascertain the type of land in relation to the municipal planning regulations, as this will set the
Table 2. Phase 1 (pre-construction)

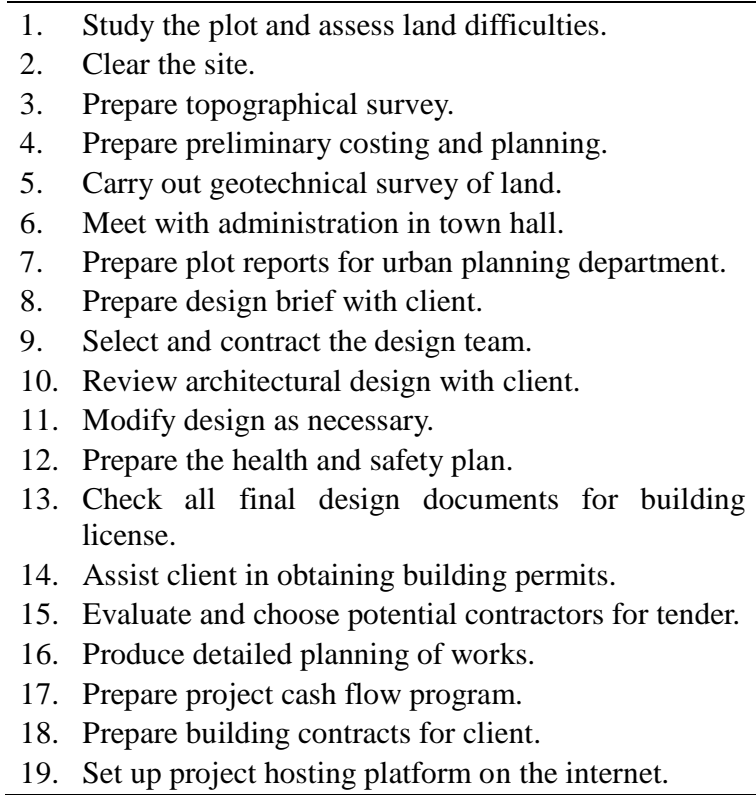

project strategy right from the start. It is essential that the client have the deeds of the land in question in his/her name and the certification of the Land Registry.

Regarding the last of the steps, an on-line project management fits the needs of expatriated clients and local companies. A tailor-made friendly interactive web site allows the client, from the comfort of his/her home, and the project team members to access and work with the most up-to-date information on the project. The clients have privileged access to secure pages, permitting exchanges of information with the project, viewing details and a summary of accounts, and keeping an accurate control on expenditure.

The client could opt to contract the company for the entire project or for phased activities. Only in the first case the company is able to implement project management principles and strategies; furthermore, an agreement must be reached and a professional services contract signed. Later on, the steps necessary to fulfil the construction phase follow, as shown in Table 3. 


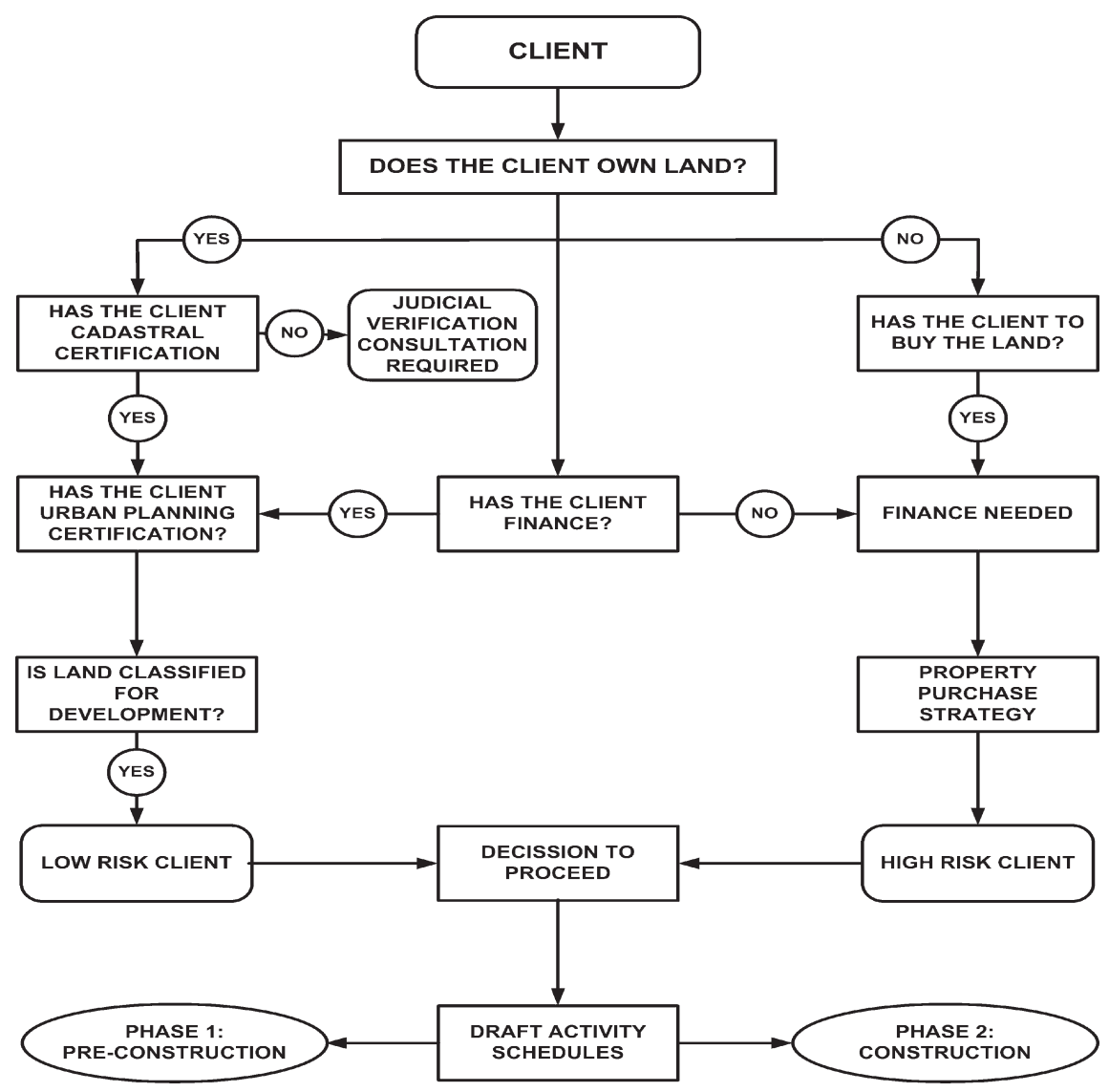

Figure 2. Flowchart of the initial stages (developed by the authors)

Table 3. Phase 2 (construction)

1. Control budget.

2. Implement quality control system for project.

3. Implement risk management system for project.

4. Plan the works.

5. Coordinate the works.

6. Supervise the works.

7. Organise regular site meetings.

8. Measure progress of executed works.

9. Issue variation orders as and when required.

10. Manage contingency allocated moneys.

11. Answer technical queries as and when required.

12. Direct reporting to the client.

13. Administer the project on the internet.

\section{PROJECT MANAGEMENT COMPANY SET UP NEEDS}

To be able to deal with urban and property development projects, much information and knowledge is needed in many fields of study. The project management company must be set up in such a way as to deal with these issues internally as much as possible. It is true that the project management company can act as a go between and just pass on queries and get the answers. But sooner or later the project management company will be caught out and 
its reputation will be jeopardised. Furthermore, subcontracting out every bit of information will only increase the fees because as a third party the project management company also has to add its percentage onto of the subcontracted consultants. At the same time the company cannot afford to employ a professional in every field of study. A balance has to be met at some point between the workload and the company investment in personnel and infrastructure.

Four requirements are proposed to meet the overall project strategy. They are the following ones:

- Legal interpretation and assessment.

- Technical expertise in urban and building issues.

- Financial strategy to run all the process.

- Administrative capacity to deliver the desired results.

It is the combination of knowledge in these different fields that is required in order to see through the whole management process.

The architect and the quantity surveyor are the professionals most needed. They can perform any function from costing to execution of the works, quality control, urban planning, setting out, health and safety plans and much more. They also get parts of the design visas stamped at their professional associations. The advantage in having one of these professionals in the company is enormous as well as saving a lot of money on subcontracting. Nevertheless, these professionals are not trained as project managers (Ling, 2003). With time, they may become project managers if they get the experience but in their true sense, they are not. Therefore, project mangers are needed to take the project right from the very start and administer it, advise it and guide it through all the processes and decisions that need to be made.

An office administrator is also needed. There is also a very strong need for an accountant or a financial adviser. The challenge is to find a team member who can carry out all these functions. A full time financial adviser is not required as many projects come with the finances already arranged. The company also needs a director who can carry out the marketing strategy and be a salesman at the same time. The company has to be proactive and go out and get the work as opposed to waiting for it to come. Table 4 shows the relationships between activity stages and professional expertise required.

\section{PROCUREMENT AND CONTRACTING STRATEGIES}

Taking into account the rigidity of the Building Law and the Contract Law for Public Agencies (Ministerio de Hacienda, 2001), the only way to implement project management principles and strategies in Spain is the company acting as a surrogate client. If the client surrogates the company, then this can act as a project manager for throughout all the cycles of the project with total authority. However,

Table 4. Relationships between activity stages and professional expertise required

\begin{tabular}{ll}
\hline STAGES & EXPERTISE \\
\hline Client assessment & Director / Financial adviser \\
Project technical assessment & Director / Project manager \\
Judicial verification & Lawyer \\
Project financial assessment & Director / Financial adviser / Accountant \\
Design procurement coordination & Architect / Project manager \\
Supervision and control & Project manager \\
Team development project liaison & Project manager \\
Project administration & Project manager \\
Marketing & Director / Project manager \\
\hline
\end{tabular}


within the Spanish Building Law, no one can override the architect (Garrido-Hernández, 2002). The way to overcome this is to include clauses, which tie the architect and quantity surveyor in that no decision or alterations can be made on site without the final approval of the surrogate client (the project management company).

Acting as a surrogate client, the project management company is responsible for administration, management, communication and coordination of the project. It appoints and directly subcontracts other consultants (architect, quantity surveyor or expert engineers) to provide other services in connection with the project. The company selects the main contractor and prepares the contract, making clear to the main contractor that the client representatives are the project managers. The client directly employs the main contractor. Figure 3 shows the contractual relations among the parties.

The project management firm gets a fee for the overall management of the project (percentage or fixed). The fees include the services during construction of an architect and a quantity surveyor who will be appointed by the company.

The procurement strategy must be launched in various fronts. The project management company holds the contracts for the design, suppliers and subcontractors. They also select the main contractor who is contracted by the client.

The procurement strategy best adopted in Spain for property development is that of competitive tendering fixed price with scope for provisional sums. The industry is made up of small suppliers and sub-contractors; the projects are small. The combination of these two elements means that there is a lot of competition amongst suppliers.

Provided that the design is prepared in advance, then several suppliers can be invited to tender for the works. Supply and fix is the most common option used. With time, two-stage tendering can be used with the most reliable suppliers; this will speed up the procurement process. The method of payment most adopted by the suppliers is that of payment upon receipt. This is because they are small suppliers who could not assume a cash flow lock up.

The procurement of the main contractor is also best made via competitive tendering. Residential building is basic and contractors already have indices for types of construction, quality

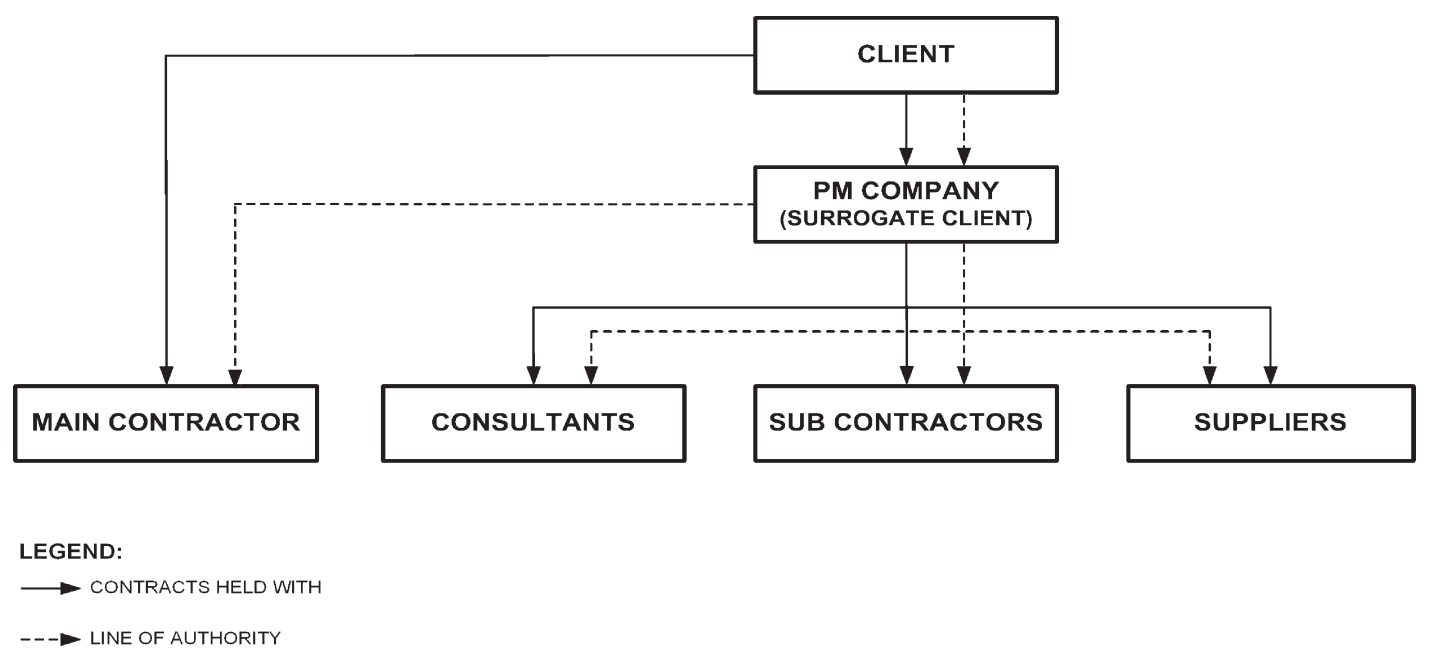

Figure 3. Contractual relationships proposed (developed by the authors) 
and site location. The tenders are usually turned around in a week and most contractors know their fares. When dealing with a client who has no financial problems and can afford fares that are a bit over the top then it is advisable given this particular situation, to opt for a bigger supplier. The reason is that bigger suppliers suffer less from logistic problems.

\section{VALIDATION AND DISCUSSION OF RESULTS}

As stated in the introduction, our model is constructed through empirical observation of a Spanish (South Mediterranean based) company for a fifteen month period. Yet this model needs to be validated. In order to test it, two different case studies were implemented; their main characteristics are summarised in Table 5. Eisenhardt (1989) thinks that at least four case studies are the right measure for analytic generalisation. Nonetheless, due to the typical long period for a complete property development, we could select only two case studies. One of the case studies stands for a simple housing development (Case A), whereas the other represents a more complex urban development process (Case B).

In both case studies, the clients were already the land titleholders and they approached the company with a general idea of their project goals (see Table 5); none of them had taken any steps in order to check the feasibility of the project: legal, technical and financial. Moreover, the organisational structures implemented were already advanced in
Table 4 and Figure 3. The project management company acted as a surrogate client of each owner, being responsible for the administration of the project. It subcontracted other professionals or companies to supply needed services.

In case $\mathrm{A}$, the client was proprietor of a single parcel of land of $3.500 \mathrm{~m}^{2}$, intending to build a single villa of high quality. In this case, no urban development was needed due to the fact that the area was already urbanized by the city council. Our preliminary questionnaire (Table 1) was filled out by the client. The risk assessment flowchart (Figure 1) was implemented and the company decided to manage the project for the client. Then, the flowchart of the initial stages, developed in Figure 2, was applied. The detailed steps followed were:

- Verification of any charges, embargoes or encumbrances of the land.

- Comparison of details supplied by the land registry against those provided by the cadastral office.

- Visual inspection of the land.

- Surveying the plot to establish boundaries and actual surface-area compared to documentation.

- If any discrepancies found, new inscription in the notary, and adjustment of the deed in the land registry and cadastral office.

- Ensuring the updating of land tax contributions.

Cadastral and urban planning certifications

Table 5. Summary of case studies

\begin{tabular}{lll}
\hline & CASE A & CASE B \\
\hline Development & Housing & Urban + Housing \\
Plot & Single & Multiple (14) \\
Area of plot & $3.500 \mathrm{~m}^{2}$ & $13.000 \mathrm{~m}^{2}$ \\
Building & Villa & Semi-detached houses \\
Quality & High & Medium \\
Land use & Urban & Urban-fit for development \\
\hline
\end{tabular}


did not relieve the responsibility for omission in the application to any rights of third parties. In this project, the original urbanization works were carried out by the local authority that charged $90 \%$ of the cost to the land owners affected. The previous owner did not pay these taxes, thus the client had to forfeit them. Finally, with all the papers in order, an official document regarding the urban planning characteristics of land was requested. This way the information needed to prepare the design of the villa was confirmed: minimum area, size and distances; maximum occupation and height; and buildability index. Once this official document was obtained, the pre-construction phase started (see Table 2) and no any other atypical problems appeared.

In case study $\mathrm{B}$, the plot was one single parcel of land $\left(13.000 \mathrm{~m}^{2}\right)$ which the client wanted to divide into 14 individual parcels for semi-detached houses of medium quality. The area was not urbanized, thus a urbanizing process was also required. The initial idea of the client was to sell off 4 plots to be able to finance the construction of the remaining 10 houses. After applying the preliminary questionnaire (Table 1) and the risk assessment flowchart (Figure 1, including the detailed steps followed in Case A) two major problems were highlighted: easements rights of a public stream and a hosepipe that ran across the original parcel. Additional reports and permits had to be requested to several public agencies, thus the project slowed down.

Furthermore, the urban development required additional documents: some for the division into plots and zoning propositions for each individual plot; others for the urbanization works. They had to be submitted to the department of urban planning in the municipality that has planning jurisdiction over the land in question. These procedures took additional time and they were just approved when the research team left the company.

\section{CONCLUSIONS}

Project management provides methodologies, tools and controls to guarantee the quality of an investment. There is evidence that project management is being slowly introduced into construction in Spain and one of its greatest areas of influence is in the urban development and residential housing sectors. It is on the Mediterranean Coast where there is great potential for its use; this is because there are many foreign clients. There is a healthy expanding market for small to medium sized firms to be able to operate within this sector. Such companies need to provide a very wide range of services to the clients, which may break out of the traditional roles of a construction project manager. Many of the companies shave to adapt to work around the Spanish Building Law with great care, as many project managers are not architects.

The paper proposes a model for the implementation of project management principles in urban and property development projects in Spain; the stages, phases and steps were outlined and contractual relationships described. The empirical research was validated by two illustrative case studies. Nevertheless, future research is needed to improve and detail the model; supplementary case studies and surveys to companies and clients are also necessary.

\section{REFERENCES}

AEDIP (2006) Contratación pública (Contracting for public agencies), retrieved on $17^{\text {th }}$ of July from http://www.aedip.org/Actividades/Publica.htm. (in Spanish).

Archibald, R. D. (1976) Managing high-technology programs and projects, New York: Wiley.

Ashworth, A. (1998) Civil engineering contractual procedures, Essex: Addison Wesley Longman Ltd.

Bartunek, J. M., Louis, M. R. (1996) Insider / outsider team research, Thousand Oaks (California): Sage. 
Barrie, D. S., Paulson, B. C. (1978) Professional construction management, New York: McGraw-Hill.

Blayse, A. M., Manley, K. (2004) Key influences on construction innovation. Construction Innovation, 4, p. 143-154.

Clark, W. (1925) The Gantt chart, New York: The Ronald Press Co.

Chakrabarty, B. K. (1998) Urban management and optimizing urban development models. Habitat International, 22(4), p. 503-522.

Chakrabarty, B. K. (2001) Urban management: concepts, principles, techniques and education. Cities, 18(5), p. 331-345.

Chopra, S., Lovejoy, W. and Yano, C. (2004) Five decades of operations management and the prospects ahead. Management Science, 50(1), p. 8-14.

Churchman, C. W. (1970) Operations research as a profession. Management Science, 17(2), p. 37-53.

Cleland, D. I., King, W. R. (1968) System analysis and project management, New York: McGrawHill.

Deming, W. E. (1986) Out of the crisis, Cambridge (Massachusetts): Center for Advanced Engineering Study (Massachusetts Institute of Technology).

Department of Defence (1966) Directive 7000.1: resources management system for the Department of Defence, Washington DC: Department of Defence.

Egan, J. (1998) Rethinking construction, London: HMSO.

Eisenhardt, K. (1989) Building theories from case study research. Academy of Management Review, 14(4), p. 532-550.

Engwall, M. (2003) No project is an island: linking projects to history and context. Research Policy, 32, p. 789-808.

Engwall, M., Jerbrant, A. (2003) The resource allocation syndrome: the prime challenge of multiproject management? International Journal of Project Management, 21, p. 403-409.

European Union (2005) Directive 18/2004 on the coordination of procedures for the award of public works contracts, public supply contracts and public service contracts, retrieved on $6^{\text {th }}$ of June from http://eur-lex.europa.eu/LexUriServ/ LexUriServ.do?uri=CELEX:32004L0018:EN:HTML.

Fayol, H. (1916) Administration industrielle et generale (Industrial and general management), Paris: Dunod (in French).
Fernández, G. R. (2005) The urbanizing agent, myth and reality. Ciudad y Territorio, 143, p. 174 .

Ferry, D. (1991) The organisation of procurement. In Cox, P. A. (ed.), Civil engineering project procedure in the European Community, London: Thomas Telford, p. 17-27.

Fewings, P. (2005) Construction project management, London: Taylor and Francis.

Gaddis, P. O. (1959) The project manager. Harvard Business Review, May-June, p. 89-97.

Gantt, H. L. (1903) A graphical daily balance in manufacture. ASME Transactions, 24, p. 1322-1336.

Garba, S. B., Al-Mubaiyedh, A. (1999) An assessment framework for public urban land management intervention. Land Use Policy, 16, p. 269-279.

Garrido-Hernández, A. (2002) El libro del director de la ejecución de la obra (The handbook of the executive inspector of construction works), Madrid: Leynfor Siglo XXI (in Spanish).

Hopp, W. J. (2004) Fifty years of management science. Management Science, 50(1), p. 1-7.

Instituto Nacional de Estadística (2003) Anuario estadístico de España 2002-2003 (Spanish statistical yearbook 2002-2003), Madrid: Instituto Nacional de Estadística (in Spanish).

International Organization for Standardization (1997) ISO 10.006: quality management: guidelines to quality in project management, Geneva: International Organization for Standardization.

Kerzner, H. (1989) Project management: a systems approach to planning, scheduling and controlling, New York: Van Nostrand Reinhold.

Kozak, M. (2002) Comparative analysis of tourist motivations by nationality and destinations. Tourist Management, 23, p. 221-232.

Knight, K. (1976) Matrix organization: a review. Journal of Management Studies, 17(2), p. 111-130.

Latham, M. (1994) Constructing the team, London: HMSO.

Ling, Y. Y. (2003) A conceptual model for selection of architects by project managers in Singapore. International Journal of Project Management, 21 , p. $135-144$.

Love, P. E. D. (2002) Influence of project type and procurement method on rework costs in building construction projects. Journal of Construction Engineering and Management-ASCE, 128(1), p. 18-29. 
Love, P. E. D., Skitmore, M. and Earl, G. (1998) Selecting a suitable procurement method for a building project. Construction Management and Economics, 16, p. 221-223.

Lum, S. K., Sim, L. L. and Malone-Lee, L. C. (2004) Market-led policy measures for urban redevelopment in Singapore. Land Use Policy, 21, p. 1-19.

Martinez-Val, R. (1996) Aeronautical engineering education in Spain - Changing needs in an evolving environment. $34^{\text {th }}$ Aerospace Sciences Meeting and Exhibit, Reno, Jan. 15-18.

Mee, J. F. (1964) Matrix organization, Summer: Business Horizons.

Ministerio de Economía (2003) Spanish tourism in figures 2002, Madrid: Ministerio de Economía.

Ministerio de Fomento (1999) Ley de Ordenación de la Edificación (Building Law), Madrid: Ministerio de Fomento (in Spanish).

Ministerio de Fomento (2001) Atlas de la vivienda (Atlas of housing), Madrid: Ministerio de Fomento (in Spanish).

Ministerio de Fomento (2004) Información estadística - Boletín $n^{\circ} 36$ (Statistical information - Issue 36), Madrid: Ministerio de Fomento (in Spanish).

Ministerio de Hacienda (2004) Informe $y$ conclusiones de la comisión de expertos para el estudio y diagnóstico de la situación de la contratación pública (Report and conclusions from the commission of experts for the analysis and diagnostic of public contracting), Madrid: Ministerio de Hacienda (in Spanish).

Ministerio de Hacienda (2001) Contract Law for Public Agencies, Madrid: Ministerio de Hacienda.

Miser, H. J. (2001) The easy chair: is OR/MS a profession? Interfaces, 31(4), p. 17-21.

Modrego-Caballero, F. (2000) Cuarenta meses de aplicación de la Ley Reguladora de la Actividad Urbanística en la Comunidad Valenciana (Forty months of implementation of the Urban Planning Law in Valencia Region). Ciudad $y$ Territorio, 123, p. 11-27 (in Spanish).

Morris, P. W. G. (1994) The management of projects, London: Thomas Telford.

Murdoch, J., Hughes, W. (2000) Construction contracts: Law and management, London: Spon Press.
Office of the Secretary of Defence and National Aeronautics and Space Administration (1962) DoD and NASA guide PERT/cost systems design, Washington DC: US Government Printing Office.

Pellicer, E. (2001) El control de gestión en las empresas consultoras de ingeniería (Management control in consulting engineering firms), Valencia: Universidad Politécnica de Valencia (in Spanish).

Pellicer, E., Garzón, O. P., Catalá, J. and Pellicer, T. M. (2006) The impact of economic globalization on the Spanish housing market. Revista Ingeniería de Construcción, 21(1), p. 23-30.

Project Management Institute (1987) Guide to the project management body of knowledge (PMBoK), Philadelphia: Project Management Institute.

Rodríguez y R. de Acuña (2006) Anuario estadístico del mercado inmobiliario español (Statistical yearbook of the Spanish real estate market), Madrid: RR de Acuña \& Ass. (in Spanish).

Romero, F., Lorente, J. L. (1996) El regímen urbanístico de la Comunidad Valenciana (Urban planning regulations in Valencia Region), Valencia: Universidad Politécnica de Valencia (in Spanish).

SEOPAN (2006) Spanish construction activity report 2005, Madrid: SEOPAN.

Stuckenbruck, L. C. (1981) The implementation of project management: the professional's handbook, Reading (Massachusetts): AddisonWesley.

Turner, J. R. (1993) The handbook of project based management, London: McGraw-Hill.

Turner, J. R. (2006) Towards a theory of project management: The nature of the project. International Journal of Project Management, 24, p. 1-3.

Watkinson, E. D. (1992) Procurement alternatives. Faculty of Building Journal (Nottingham), p. 4-6.

Winch, G. M. (2002) Managing construction projects, London: Blackwell Pub. Co.

Winch, G. M. (2006) Towards a theory of construction as production by projects. Building Research and Information, 34(2), p. 164-174.

Wren, D. A. (1994) The evolution of management thought, New York: Wiley. 
SANTRAUKA

PROJEKTŲ VALDYMO PRINCIPŲ TAIKYMAS ISPANIJOS GYVENAMŲJŲ TERITORIJŲ PLĖTRAI

\section{Eugenio PELLICER, Richard VICTORY}

Urbanistinès plètros ir su ja susijusios gyvenamujjų pastatų plètros ryšiai su statybos pramone yra glaudūs. Anglosaksiškosios šalys šioje pramonės šakoje dažnai ima valdyti projektus. Tačiau apžvelgus literatūrą, nepaaiškèjo, kaip projektų valdymas taikomas valdyti žemei ir nuosavybei. Be to, projektų valdymas - retas dalykas Ispanijos statybos pramoneje, netgi privačiame sektoriuje. Tradicinis pramonės šakos nelankstumas ir protekcionizmas, kaip ir Ispanijos statybos ịstatymai, sukuria situaciją, kad inovacijos ịgyvendinamos sunkiai. Žadama, kad mažos ir vidutinès projektų valdymo įmonès galès ateityje teikti įvairiausių paslaugų privatiems klientams. Šiame straipsnyje kalbama, kaip pamėginti įdiegti projektų valdymo principus Ispanijos Viduržemio jūros pakrantès gyvenamujų teritorijų plètrai. Pasirinkta indukcinè metodika. Paaiškinus Ispanijos nekilnojamojo turto rinkos procesą, siūlomas bazinis planas, kaip diegti projektų valdymą. Ivvertinama projekto ir kliento rizika, pateikiamos preliminarios anketos, etapai ir žingsniai, aptariamas su profesine patirtimi susijęs įmonès organizavimas, pirkimų strategijos ir sutarčių valdomi santykiai. Galiausiai modelis patikrinamas dviem būdingais atvejo tyrimais. 